\title{
WHAT KIND OF CITIZEN? EDUCATING OUR CHILDREN FOR THE COMMON GOOD
}

Joel Westheimer

Teachers College Press. 2015. pp. 121

ISBN: 0807756350

\section{Reviewed by Elena V. Toukan}

Ontario Institute for Studies in Education

University of Toronto, Canada

elena.vanderdussen@utoronto.ca

How should schools educate for democracy? This is the question that Joel Westheimer grapples with in What Kind of Citizen? Educating Our Children for the Common Good. $\mathrm{He}$ argues that the purpose of schooling in democratic societies like the United States must prioritise the education of democratic citizens who are able to base their social participation on critical thinking. While Westheimer's research on the practice and politics of educating for democracy, social justice education, and service learning in the early 2000s is already well known among many education scholars, this accessible volume introduces his research and conclusions to a new group of readers, with a special focus on the concerns of teachers.

In the first four chapters, Westheimer astutely identifies and analyses some of the pressing challenges that educators face in striving to connect with their students to help them to do well in school. He begins the first chapter with his own teaching experience as a middle school teacher in New York City's public schools in the mid1980s. Entering the teaching profession with idealism, Westheimer found creative ways to engage students who struggled with "doing school" by encouraging his students to think critically about things that matter to them. The second chapter challenges this hopeful narrative by proposing that in today's educational climate, critical thinking is under attack. Pressures from policymakers, corporate interests, philanthropists and parents are among the sources of a shift in educational priorities towards seeing schools primarily as instruments for individual success. Ideals of "success" do not look the same for all students, however, as higher-achieving (often wealthier) students and schools are being allotted more curricular time to focus on social studies and citizenship education, consequently widening the "civic opportunity gap" against the broader trend to narrow

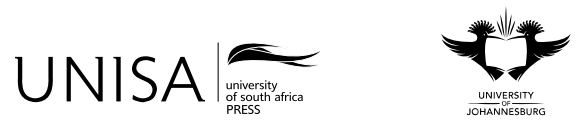

Education as Change

Volume 21 | Number 1 | 2017 | pp. 193-197

DOI: http://dx.doi.org/10.17159/1947-9417/2017/2280 Print ISSN 1682-3206 | Online 1947-9417

www.educationaschange.co.za

(C) The Author (2017) 
the curriculum towards maths and literacy subjects that are evaluated in standardised assessments. Along with the narrowing of the curriculum comes a watering down of remaining social science and history education to focus only on "positive" perspectives of American history and downplay the country's legacy of civil disobedience and protest. Such trends are highly problematic in an ostensibly democratic society, as Westheimer points out: "There is a certain irony...to the argument that schools in a democratic nation can better prepare students to be democratic citizens by encouraging deference to authority and scourging lessons about social movements and social change" $(2015,17)$.

Chapter 3 explores implications for teachers in this retreat from critical thinking in schools. Hearkening back to when teaching practice was rarely interfered with during his tenure as a school teacher, Westheimer sees the increasing scrutiny of teachers' performance as a symptom of a growing fixation on standardising classroom practices. He describes this movement towards standardisation as "a solution in search of a problem", noting that a concern for "sameness" is not necessarily a guarantee of quality. To the contrary, Westheimer is deeply suspicious that a bureaucratic push for conformity and accountability has much to do with quality at all, as aspirations for imaginative, creative and effective teaching are replaced with mandates for compliance above all. This surveillance results in a de-professionalisation of teaching, as scripted instruction and regimented curricular packages systematically restrict teacher autonomy. Westheimer traces some of the roots of this shift towards standardisation, retreat from critical thinking, and de-professionalisation of teachers in Chapter 4. As political concerns for student success manifest in calls for accountability, the relative importance placed on what could be measured through wide-scale, standardised means (e.g. students' abilities to solve maths problems and determine sentence comprehension) become substantially emphasised over what cannot be easily measured. As this narrow metric is increasingly mobilised as an anemic indicator of educational quality, the curriculum is consequently emaciated. Westheimer suggests that the most disturbing consequence of this process has been the diminished value ascribed to any other educational activity, from the arts to breakfast programmes, to the point that such forms of education feel the need to justify their existence in relation to leading to better test scores or academic performance in maths or literacy. While it is true that students need to know how to read, write, and understand how to carry out basic mathematic functions, these "basics" are not sufficient if children cannot connect what they learn to matters of social concern - a core element of democratic citizenship.

In Chapter 5, Westheimer raises the point that beyond the general "head-nodding agreement" that citizenship education is important, the way that one teacher, parent, or student defines a "good citizen" might be entirely contradictory to another. Are good citizens compliant with the norms of punctuality, respect and personal responsibility, or are they defiant of injustice and systemic oppression? Is a personally-responsible tax payer a model of a good citizen? If so, would their voice and opinion matter more than someone who relies on social assistance? These and other conceptions of good 
citizenship are conveyed both explicitly through intentional content and instruction, and implicitly through the tacit knowledge of the hidden curriculum. For Westheimer, the barometer for citizenship is his ideal of democracy, and the question of how likely it is that schooling will enable or prevent someone from participating fully and equally in a democratic society.

From here Westheimer describes three "types" of citizens: the personally responsible citizen, the participatory citizen, and the social justice-oriented citizen. He notes in Chapter 6 that in his experience and research, programmes and pedagogies that focus on educating the personally responsible citizen are in the vast majority, valuing responsibility in the community, working and paying taxes, picking up litter, giving blood, recycling, helping those in need, giving to charity, volunteering, obeying laws, etc. Westheimer points out that although developing positive character attributes, contributing to charity, and volunteering are laudable traits for any populace, there is nothing inherently democratic in them. In fact, uncritical conformity to behavioural norms can be characteristically undemocratic, and we should be suspicious of politicians who advocate volunteerism as an alternative to appropriate social policy and organisation. "Participatory" citizens are considered to go beyond personal responsibility to be the "organisers" and leaders of community initiatives to care for those in need, promote economic development and clean up the environment. Meanwhile, "social justiceoriented" citizens critically assess structural and systemic causes of injustice, and strive to change established systems and structures that reproduce patterns of injustice over time. It is clear from his analysis in Chapter 7 that, of the three "types" described, Westheimer considers them to represent a continuum with the "social justice-oriented" citizen the most suitable type for a democratic society, and the "personally responsible" citizen the most problematic in terms of serving to maintain the status quo at best, or in fact contributing to greater pedagogical and political authoritarianism at worst.

The concluding three chapters of the book apply Westheimer's analysis of the challenges of current citizenship education and his typology of possible approaches to the question of implementation. Chapter 8 therefore presents a series of brief case studies that Westheimer uses to showcase classroom experiences that aim to connect learning with civic goals. He complements these real-life examples with guides for teachers and for parents to engage students in critical thinking and community action. Chapter 9 explores seven common "myths" that impede educators and policy makers from embracing critical thinking in education. In describing the first myth, Westheimer addresses the earlier-mentioned assumptions about equating national standards with quality assurance, while in the second he counters the rise in treating signs of dissent or rebellion against the standardisation regime with medication. Myths three and four speak to challenges that educators might face in their intentions to promote critical thinking, in that democratic thinking can only be taught in a democratic (school) environment, and that knowledge must always precede action in community-based experiences. Number five looks at the critiques that teachers who care about critical thinking supposedly do 
not care about facts or basic skills; number six counters the argument that politics should be kept out of schools as a "neutral" learning environment; and finally, number seven suggests that community-based experiences do not always have to be "successful" to be meaningful in the education of good citizens, since it is more important that experiences be authentic. Westheimer believes that these myths have damaged the pursuit of democratic education, and must be eradicated in order for teachers to achieve different results in their practice. The final chapter in this book summarises the book's main theme that democratic societies place special requirements on teaching and learning to teach students how to question and think critically, in order to be able to promote the change that moves democracy forward.

Westheimer's book undoubtedly provides a comprehensive, useful guide for educators to consider their own teaching practice, along with some of the shortand long-term efforts they can make to better align their teaching with the values of critical thinking for social justice. Readers will benefit from the insightful, on-point analysis of the role that standardisation has played in the present regime of de-skilling the teaching profession to narrow curriculum provisions of the basics of literacy and mathematics. As a theoretical work, Westheimer's analysis and typology of "kinds" of citizens raises many questions. Are these categories mutually exclusive, or would a social justice-oriented citizen also undertake "participatory" actions like give blood and organise a food drive? Westheimer's typology does not seem to account for these kinds of interrelationships among the three (along with potentially other) dimensions of democratic citizenship that may be more multifaceted, nuanced, and temporally shifting. Could not first-hand personal experience through community service and project organisation deepen students' intrinsic motivation and insights for structural change and political engagement? Can an over-emphasis on structural and systemic problems and solutions in fact promote individual passivity and dampen agency, as the scope of seemingly legitimate channels for action are narrowed? And can the fragmentation of thinking and analysing from participating and doing inadvertently lead to a sense of elitism between "thinkers" and "doers"? In his own findings, for example, Westheimer notes that the students surveyed in the social justice-oriented programme in fact reported less of a sense of agency and participation than their counterparts in the more participatory-oriented programme.

Because Westheimer does not explicitly define what his notions of "democracy" or "democratic values" are, we are left to infer that his conception of democratic citizenship is informed by those characteristics and actions of the "social justice-oriented citizen" described in his schema. A democratic citizen in this sense is thus identified primarily through political and structural channels rather than individual or communal agency, on critical social and policy analysis rather than collective organisation and personal ethics. This is not to say that Westheimer does not acknowledge the value of all of these potential aims of education - in fact the personal and collective dimensions of citizenship development are also addressed in the "social justice-oriented" case that 
he profiles - but rather that he does not necessarily associate them with this working definition of democracy. Beyond this theoretical construct of who contributes to social change, there is little accounting for the personal, cultural, or systemic barriers to taking actions that correspond with the types that he proposes.

These questions taken into account, What Kind of Citizen? provides a thoughtprovoking opportunity for educators in particular to analyse the underlying intentions and messages of their own civics and citizen education programmes, and to consider the all-important questions of the aims of their efforts to educate change-oriented, criticallyengaged citizens in a democratic ideal of "the good". 